\title{
PENERAPAN METODE EKSPERIMEN BERBANTUAN SOFTWARE PhET PADA MATERI LISTRIK DINAMIS DITINJAU DARI KEMANDIRIAN BELAJAR SISWA KELAS X MAN SINTANG
}

\author{
Dwi Fajar Saputri ${ }^{*}$, Arif Dwi Rahman ${ }^{2}$ \\ ${ }^{1}$ Pendidikan Fisika, IKIP PGRI Pontianak, Jl. Ampera No 88, Pontianak \\ ${ }^{2}$ SMK Negeri 1 Dedai, Dusun Kederas Kec. Dedai, Sintang \\ *E-mail: dwifajar24@gmail.com
}

\begin{abstract}
This research aims to investigate the effects of expiremental learning using software PhET for student learning outcomes reviewed by learning independence student. The research is quasy experimental design, with factorial design $2 \times 3$. The research samples are the student of XA as the experimental class and the student of $X B$ as the control class. The instruments were test for colecting data of learning outcome and the questionnaire for colecting data of learning indepence student. The result it can be concluded that: 1) There are difference of result of learning outcomes of implementation by experimental learning using software PhET and by conventional learning, the result of learning outcomes of implementation by experimental learning using software PhET better than of result of learning by conventional learning; 2) There are difference of result of learning outcomes in groups of students who have high, medium and low learning independence; 3) There is no interaction beetween learning methods and learning independence on student learning outcomes.
\end{abstract}

Keywords: experimental learning, software PhET, learning outcomes, learning independence.

\begin{tabular}{|c|c|}
\hline $\begin{array}{l}\text { Perkembangan } \\
\text { ngetahuan dan teknologi saat ini } \\
\text { mpunyai pengaruh besar terhadap } \\
\text { ddidikan fisika di sekolah. Salah } \\
\text { u pengaruh tersebut yaitu pada cara } \\
\text { nyampaikan materi pelajaran } \\
\text { ka. Fisika sebagai salah satu ilmu } \\
\text { ig menarik untuk dikuasai oleh } \\
\text { wa yang bertujuan untuk dapat } \\
\text { pikir logis, kritis, memiliki sifat } \\
\text { yektif, disiplin dalam } \\
\text { nyelesaikan }\end{array}$ & $\begin{array}{l}\text { permasalahan (Yuniar, dkk, 2015). } \\
\text { Sehingga di dalam penyampaian } \\
\text { materinya diperlukan cara mengajar } \\
\text { yang baik dan waktu yang lama, } \\
\text { sehingga siswa dapat memahami } \\
\text { konsep fisika dengan benar. } \\
\text { Pembelajaran Fisika hendaknya } \\
\text { berorientasi pada keterampilan proses } \\
\text { dengan melakukan eksperimen } \\
\text { sehingga siswa mendapatkan } \\
\text { kesempatan } \\
\text { berinteraksi dengan obyek konkrit }\end{array}$ \\
\hline
\end{tabular}


sampai dengan penemuan konsep. Menurut Djamarah (dalam Tutut dkk, 2014) metode pembelajaran konvensional adalah metode pembelajaran tradisional atau disebut juga dengan metode ceramah, karena metode ini biasa dipergunakan dalam proses belajar dan mengajar. Ujang Sukandi menjelaskan pendekatan konvensional ditandai dengan keaktifan didominasi oleh guru dibanding oleh siswa, dalam hal ini ketika guru mengajar lebih banyak menjelaskan konsep bukan kompetensi, dengan bertujuan agar siswa mengetahui sesuatu bukan melakukan sesuatu, dengan kata lain dapat dikatakan dalam proses pembelajaran siswa lebih banyak mendengarkan (dalam Tutut dkk, 2014). Sehingga dapat dikatakan pembelajaran konvensional yang merupakan pembelajaran menggunakan konvensional adalah proses pembelajarannya guru menekankan kepada siswa untuk mengetahui suatu konsep dari penjelasan guru tanpa mengaktifkan siswa untuk memverifikasi suatu konsep, dan metode yang digunakan guru ketika mengajar adalah metode ceramah. Hal ini sama seperti yang ditemui di MAN Sintang dalam proses pembelajaran di kelas.

Berdasarkan hasil observasi yang telah dilakukan di MAN Sintang, ketika guru mengajar di kelas diketahui guru lebih banyak menjelaskan konsep kepada siswa dengan cara ceramah dan siswa terlihat hanya mendengarkan dan mencatat apa yang dijelaskan oleh guru. Pembelajaran ini akan membuat siswa merasa bosan karena guru lebih banyak menjelaskan materi di depan kelas, siswa tidak melakukan eksperimen untuk memverifikasi materi yang sedang dipelajari. Padahal beberapa materi didalam pembelajaran fisika memerlukan verifikasi agar lebih mudah dipahami siswa terlebih untuk materi yang bersifat abstrak. Pembelajaran seperti ini menyebabkan siswa mengalami kesulitan dalam memahami materi yang bersifat abstrak salah satunya pada materi listrik. Hal seperti inilah yang yang menyebabkan rendahnya hasil belajar yang diperoleh.

Banyak metode pembelajaran yang bisa mengaktifkan siswa dan membuat materi abstrak menjadi kongkret, salah satunya yaitu metode eksperimen. Menurut Djamarah dan Zain (2010) metode eksperimen adalah cara penyajian pelajaran, dimana siswa melakukan percobaan dengan mengalami dan membuktikan sendiri sesuatu yang dipelajari. Albertus, dkk (2012) menyebutkan kegiatan laboratorium (praktikum) secara virtual, yaitu pemanfaatan suatu laboratorium untuk mewujudkan konsep yang abstrak ke dalam visualisasi dengan bantuan teknologi konputer. Dengan memanfaatkan laboratorium komputer, virtual laboratory dapat digunakan sebagai alternatif dalam mengatasi masalah pelaksanaan eksperimen di MAN Sintang.

Saat ini banyak sekali layanan virtual laboratory yang dikembangkan, salah satunya adalah software PhET. Menurut Prihatiningtyas, dkk. (2013) "PhET adalah sebuah virtual laboratory yang didalamnya memuat program simulasi interaktif yang dibuat untuk membantu proses pembelajaran fisika dan dirancang sedemikian rupa agar 
terlihat menarik dan terbuka untuk semua pelajar yang memberikan umpan balik dari animasi kepada para siswa". Oleh karena itu software PhET ini sangat cocok untuk digunakan sebagai alternatif untuk menggantikan laboratorium fisika yang kurang memadai, dengan menginstal software PhET disetiap komputer yang ada di laboratorium komputer kegiatan eksperimen/ praktikum siswa dapat terlaksana. Menurut Adam, dkk dalam Siregar (2016) mengemukakan bahwa simulasi PhET mampu memvisualisasikan dengan baik konsep materi yang awalnya sulit untuk dipahami ketika pembelajaran disajikan dengan metode ceramah. Sehingga pada penelitian ini pembelajaran yang dilakukan menggunakan metode eksperimen dengan bantuan Software PhET.

Software PhET masih menggunakan bahasa asing sebagai pengantar dan masih belum memiliki arahan proses pembelajaran sesuai dengan tujuan pembelajaran yang ingin dicapai. Sebagai bentuk optimalisasi penggunaan software PhET agar sesuai dengan Standar Kompetensi (SK) dan Kompetensi Dasar (KD) yang diinginkan, maka dibutuhkan LKS (Lembar Kerja Siswa) sebagai panduan dalam melakukan eksperimen. Penelitian yang dilakukan Sari, dkk (2015) menunjukkan LKS dengan menggunakan simulasi PhET sangat menarik, mudah dan sangat bermanfaat, serta dapat dijadikan media pembelajaran sehingga hasil belajar siswa lebih dari $80 \%$ mencapai kelulusan dalam aspek kognitif dan afektif. Sehingga, penggunaan LKS (lembar Kerja
Siswa) dengan software PhET ini diharapkan dapat membuat proses pembelajaran akan lebih menarik dan lebih membantu siswa dalam bereksperimen menemukan konsepkonsep materi fisika dengan melakukan praktikum. Contohnya pada materi arus listrik dan hambatan listrik, siswa dituntut untuk memahami konsep-konsep yang ada serta membuktikan arus listrik dan bagaimana arus yang terjadi pada suatu rangkaian listrik yang tidak bisa dilihat langsung oleh mata secara nyata. Untuk mempermudah siswa memahaminya, maka siswa tersebut harus mempraktekkan dengan melakukan praktikum sehingga dengan mengalami langsung siswa dapat menyimpulkan konsep-konsep yang ada pada materi tersebut serta dapat menjelaskannya dengan benar. Nurhayati (2014) menyimpulkan bahwa pembelajaran dengan metode demontrasi berbantuan software PhET lebih baik dari pada pembelajaran konvensional biasa, dengan nilai efek size sebesar 0,80 . Selain itu Aziz, dkk (2014) menemukan keterlaksanaan pembelajaran menggunakan model inkuiri berbantuan program simulasi PhET sangat baik dan aktivitas siswa dalam pembelajaran baik. Berdasarkan penelitian yang telah dilakukan terdahulu dapat diketahui bahwa pembelajaran dengan metode eksperimen menggunakan software PhET atau media animasi lainnya dapat meningkatkan hasil belajar siswa dari pada menggunakan pembelajaran konvensional biasa.

Hasil belajar siswa juga dipengaruhi oleh karakteristik siswa. Salah satu karakteristik siswa yang dapat mempengaruhi keberhasilan 
penerapan suatu metode pembelajaran adalah kemandirian belajar siswa. Menurut Sugandi (2013) kemandirian belajar adalah suatu sikap yang memiliki karakteristik berinisiatif belajar, mendiagnosis kebutuhan belajar, menetapkan tujuan belajar, memonitor, mengatur dan mengontrol kinerja belajar serta mampu menerapkan strategi belajar dan mengevaluasi proses dan hasil belajar. Kemandirian merupakan salah satu unsur penting yang harus dimiliki siswa dalam proses pembelajaran. Setiap siswa memiliki kemandirian yang berbeda yang mempengaruhi bagaimana siswa dalam menerima pembelajaran yang diberikan selama proses pembelajaran. Siswa yang memiliki kemandirian belajar yang tinggi akan menggunakan waktunya untuk mencari sendiri referensi belajar di sekolah maupun di luar sekolah. Sedangkan siswa yang memiliki kemandirian belajar yang rendang cenderung menerima saja apa yang diberikan oleh guru sehingga wawasannya kurang. Hal tersebut akan berpengaruh pada hasil belajar yang didapat.

Berdasarkan uraian tersebut, maka masalah pada penelitian ini adalah Apakah terdapat perbedaan hasil belajar siswa yang diberi pembelajaran dengan metode eksperimen menggunakan software PhET dibandingkan dengan pembelajaran konvensional ditinjau dari kemandirian belajar siswa kelas X MAN Sintang.

\section{METODE PENELITIAN}

Bentuk penelitian ini merupakan quasy eksperimen dengan rancangan desain faktorial $2 \times 3$. Seperti ditunjukkan pada Tabel 1.

Tabel 1. Desain Faktorial Penelitian

\begin{tabular}{cccc}
\hline \multirow{2}{*}{ Kelas } & \multicolumn{3}{c}{ Kemandirian Belajar $(\boldsymbol{b})$} \\
\cline { 2 - 4 } & Tinggi $\left(b_{1}\right)$ & Sedang $\left(b_{2}\right)$ & Rendah $\left(b_{3}\right)$ \\
\hline Eksperimen & $(a b)_{11}$ & $(a b)_{12}$ & $(a b)_{13}$ \\
Kontrol & $(a b)_{21}$ & $(a b)_{22}$ & $(a b)_{23}$ \\
\hline
\end{tabular}

Tabel 1. merupakan desain faktorial penelitian untukmelihat pengaruh dan interaksi metode pembelajaran dan perbedaan kemandirian belajar siswa terhadap hasil belajar pada listrik dinamis. Cakupan materi listrik dinamis dalam penelitian ini meliputi tentang arus listrik dan hambatan litrik.

Kelas eksperimen yaitu kelas yang diberi perlakuan pembelajaran yang menggunakan software $\operatorname{PhET}\left(a_{1}\right)$ dan kelas kontrol adalah kelas yang diberi pembelajaran konvensional $\quad\left(a_{2}\right)$. Perbedaan kemandirian belajar siswa dikategorikan menjadi kemandirian belajar tinggi $\left(b_{1}\right)$, sedang $\left(b_{2}\right)$ dan rendah $\left(b_{3}\right)$.

Populasi penelitian ini adalah siswa kelas $\mathrm{X}$ MAN Sintang yang terdiri dari lima kelas. Sedangkan sampel penelitian ini adalah dua kelas diambil dengan teknik cluster random sampling, sehingga didapatdua kelas yaitu kelas XA sebagai kelas eksperimen kelas XB sebagai kelas kontrol.

Teknik pengumpul data yang digunakan yaitu teknik komunikasi tidak langsung dan teknik pengukuran. Instrumen penelitian 
berupa angket kemandirian belajar dan tes essai. Soal tes essai yang digunakan berjumlah 7 soal dan telah memenuhi kriteria valid dengan reliabilitas sedang. Pengolahan data penelitian diawali dengan uji prasyarat analisis berupa uji normalitas data dengan uji lilliefors dan uji homogenitas data dengan uji bartlett. Hasil uji prasyarat analisis menunjukkan bahwa data yang digunakan normal dan homogen sehingga dilanjutkan dengan pengujian hipotesis menggunakan analisis variansi dua jalan $(2 \times 3)$ dengan sel tak sama.

\section{HASIL DAN PEMBAHASAN Hasil Penelitian}

Data hasil belajar siswa berdasarkan perbedaan metode pembelajaran dapat dilihat pada Tabel 2. Sedangkan data hasil belajar siswa berdasarkan perbedaan metode pembelajaran ditinjau dari kemandirian belajar siswa dapat dilihat pada Tabel 3 . Berdasarkan Tabel 2 diketahui bahwa pada kelas eksperimen yaitu kelas yang diterapkan metode eksperimen menggunakan software PhET terdiri dari 35 siswa mempunyai nilai ratarata sebesar 82,52.

Tabel 2. Hasil Belajar Siswa Berdasarkan Metode Pembelajaran

\begin{tabular}{lccccc}
\hline \multicolumn{1}{c}{ Pembelajaran } & $\begin{array}{c}\text { Jumlah } \\
\text { Data }\end{array}$ & $\begin{array}{c}\text { Nilai } \\
\text { Min }\end{array}$ & $\begin{array}{c}\text { Nilai } \\
\text { Maks }\end{array}$ & $\begin{array}{c}\text { Nilai } \\
\text { Rata-rata }\end{array}$ & sd \\
\hline $\begin{array}{l}\text { Metode eksperimen } \\
\text { menggunakan software PhET }\end{array}$ & 35 & 67,69 & 98,77 & 82,52 & 7,34 \\
Konvensional & 35 & 67,69 & 93,85 & 78,51 & 7,98 \\
\hline
\end{tabular}

Tabel 2 juga menunjukkan nilai rata-rata kelas kontrol yaitu kelas yang diterapkan pembelajaran konvensional sebesar 78,51 terdiri dari 35 siswa. Sehingga dapat dikatakan bahwa nilai rata-rata hasil belajar pada kelas eksperimen yang diberi pembelajaran dengan metode eksperimen menggunakan software PhET lebih tinggi dari pada nilai ratarata hasil belajar pada kelas kontrol yang diberi pembelajaran konvensional. Untuk nilai tertinggi pada kelas eksperimen juga lebih tinggi yaitu sebesar 98,77, sedangkan nilai tertinggi pada kelas kontrol hanya sebesar 93,85 saja. Dan nilai standar deviasi antara kelas kontrol dan eksperimen tidak jauh berbeda, hal ini menunjukkan variasi nilai baik di kelas ekperimen dan kontrol tidak menyimpang jauh dari nilai rata-rata.

Tabel 3. Hasil Belajar Siswa ditinjau dari Kemandirian Belajar Siswa

\begin{tabular}{cccccc}
\hline \multirow{2}{*}{ Pembelajaran } & \multicolumn{4}{c}{ Kemandirian Belajar } & \multirow{2}{*}{\begin{tabular}{c}
\multirow{2}{*}{ Rata- } \\
Rata
\end{tabular}} \\
\cline { 2 - 5 } & & Tinggi & Sedang & Rendah & \\
\hline Metode Eksperimen & $\mathrm{N}$ & 13 & 7 & 15 & \\
Menggunakan Software PhET & $\bar{X}$ & 87,48 & 81,98 & 76,05 & 82,64 \\
Konvensional & $\mathrm{N}$ & 10 & 11 & 14 & \\
& $\bar{X}$ & 82,00 & 78,46 & 78,46 & 78,84 \\
\hline Rerata Marginal & & 84,73 & 80,22 & 77,26 & \\
\hline
\end{tabular}


Berdasarkan Tabel 3 diketahui bahwa untuk kelas eksperimen yang diberi pembelajaran dengan metode eksperimen menggunakan software PhET terdapat 13 siswa yang termasuk kategori kemandirian belajar tinggi, 7 siswa termasuk kemandirian belajar sedang dan 15 siswa termasuk kategori kemandirian belajar rendah. Sedangkan pada kelas kontrol yang diberi pembelajaran konvensional terdapat 10 siswa yang termasuk kategori kemandirian belajar tinggi, 11 siswa termasuk kategori kemandirian sedang dan 14 siswa termasuk kemandirian belajar rendah.

Nilai rata-rata keseluruhan nilai hasil belajarsiswa yang diberi pembelajaran dengan metode eksperimen menggunakan software PhET lebih tinggi yaitu sebesar 82,64 sedangkan rata-rata keseluruhan hasil belajarsiswa yang diberi pembelajaran konvensional hanya sebesar 78,84.

Tabel 3 juga menunjukkan pada kelas eksperimen yang diberi perlakukan metode eksperimen menggunakan software PhET pada kelompok siswa yang memiliki kemandirian tinggi nilainya lebih tinggi dibandingkan nilai kemandirian siswa di kelas kontrol $(87,48>$ 82,00), sedangkan pada kelompok siswa yang memiliki kemandirian rendah hasil belajar kelas eksperimen lebih rendah dibandingkan hasil belajar kelas kontrol. Sehingga dapat dikatakan bahwa dalam pembelajaran yang menggunakan metode eksperimen berbantuan software PhET anak yang memiliki kemandirian belajar yang tinggi lebih dapat memahami pelajaran karena mereka dapat belajar sendiri dan memiliki kemapuan untuk mengerjakannya dengan mandiri. Sebaliknya pada kelas yang diterapkan pembelajaran konvensional hasil belaajr siswa yang memiliki kemandirian rendah nilainya lebih tinggi dibandingkan nilai anak yang diberi pembelajaran yang diterapkan metode eksperimen menggunakan Software PhET, hai ini disebabkan pada pembelajaran konvensional tidak menuntut siswa untuk belajar mandiri, sedangkan di keals eksperimen dituntut untuk mandiri, sehingga siswa yang memiliki kemandirian rendah memperoleh nilai rendah di kelas eksperimen.

Tujuan dalam penelitian ini juga ingin mengetahui apakah terdapat perbedaan hasil belajar siswa yang diberi pembelajaran menerapkan metode eksperimen menggunakan Software PhET dengan hasil belajar siswa yang diberi pembelajaran konvensional, oleh sebab itu perlu dilakukan uji hipotesis. Sebelum melakukan uji hipotesis, dilakukan terlebih dahulu uji prasyarat analisis yaitu uji normalitas dan homogenitas.

Untuk menghitung normalitas masing-masing sampel digunakan uji lilliefors. Di mana data yang diperoleh dapat dilihat pada Tabel 4 . Berdasarkan Tabel 4 diketahui bahwa nilai $L_{o b s}$ pada kelas eksperimen dan kelas kontrol masing-masing sebesar 0,072 dan 0,148. Untuk kelas eksperimen nilai $L_{\text {obs }}<L_{\text {tabel }}$ atau $0,072<0,150$ yang berarti data hasil belajar siswa pada kelas eksperimen berdistribusi normal. Begitu juga dengan kelas kontrol, nilai $L_{o b s}<$ $L_{\text {tabel }}$ atau 0,148 $<0,150$ yang berarti data hasil belajar siswa pada kelas kontrol juga berditribusi normal. 
Tabel 4. Data Hasil Uji Normalitas

\begin{tabular}{lccccc}
\hline \multicolumn{1}{c}{ Sampel } & $\mathbf{N}$ & $\boldsymbol{L}_{\boldsymbol{o b s} \boldsymbol{s}}$ & $\boldsymbol{L}_{\text {tabel }}$ & $\begin{array}{c}\text { Keputusan } \\
\text { Uji }\end{array}$ & Kesimpulan \\
\hline Kelas Eksperimen & 35 & 0,072 & 0,150 & $\mathrm{H}_{0}$ diterima & Normal \\
Kelas kontrol & 35 & 0,148 & 0,150 & $\mathrm{H}_{0}$ diterima & Normal \\
Kemandirian Tinggi & 23 & 0,136 & 0,190 & $\mathrm{H}_{0}$ diterima & Normal \\
Kemandirian Sedang & 18 & 0,124 & 0,200 & $\mathrm{H}_{0}$ diterima & Normal \\
Kemandirian Rendah & 29 & 0,117 & 0,173 & $\mathrm{H}_{0}$ diterima & Normal \\
\hline
\end{tabular}

Berdasarkan Tabel 4 diketahui bahwa pada ketiga kategori kemandirian belajar memiliki nilai $L_{\text {obs }}<L_{\text {tabel }} . \quad$ Untuk kategori kemandirian belajar tinggi nilai $L_{\text {obs }}<L_{\text {tabel }}$ atau $0,136<0,190$ yang berarti data hasil belajar siswa pada kategori kemandirian belajar tinggi berdistribusi normal. Untuk kategori kemandirian belajar sedang nilai $L_{\text {obs }}<L_{\text {tabel }}$ atau $0,124<0,200$ yang berarti data hasil belajar siswa pada kategori kemandirian sedang berdistribusi normal. Begitu pula dengan kategori kemandirian belajar rendah yang memiliki nilai $L_{o b s}<$ $L_{\text {tabel }}$ atau $0,117<0,173$ yang berarti data hasil belajar siswa pada kategori kemandirian belajar rendah berdistribusi normal.

Tabel 5. Uji Homogenitas Metode Pembelajaran Menggunakan Uji F

\begin{tabular}{ccccc}
\hline & $\mathbf{F}_{\text {obs }}$ & $\mathbf{F}_{\text {Tabel }}$ & Keputusan uji & Kesimpulan \\
\hline Pembelajaran & 1,182 & 1,77 & $\mathrm{H}_{0}$ diterima & Homogen \\
\hline
\end{tabular}

Berdasarkan Tabel 5 diketahui bahwa hasil uji homogenitas berdasarkan metode pembelajaran yaitu pembelajaran dengan metode eksperimen menggunakan software PhET dan pembelajaran konvensional menghasilkan nilai untuk $F_{o b s}$ sebesar 1,182 ini menunjukkan bahwa nilai $F_{\text {obs }}<F_{\text {tabel }}$ yang berarti kedua data tersebut homogen.
Berdasarkan Tabel 6 diketahui bahwa hasil uji homogenitas berdasarkan kategori kemandirian belajar siswa menghasilkan nilai untuk $x^{2}{ }_{o b s}$ sebesar 0,016, ini menunjukkan bahwa nilai $x^{2}{ }_{o b s}<$ $x^{2}{ }_{\text {tabel }}$ atau $0,016<5,991$ yang berarti ketiga data tersebut homogen.

Tabel 6. Uji Homogenitas Kemandirian Belajar Menggunakan Uji Bartlett

\begin{tabular}{ccccc}
\hline & $\boldsymbol{x}_{\boldsymbol{o b s}}^{\mathbf{2}}$ & $\boldsymbol{x}_{\boldsymbol{t a b e l}}^{\mathbf{2}}$ & Keputusan uji & Kesimpulan \\
\hline Kemandirian Belajar & 0,016 & 5,991 & $\mathrm{H}_{0}$ diterima & Homogen \\
\hline
\end{tabular}

Setelah uji prasyarat anava yaitu uji normalitas dan uji homogenitas telah terpenuhi, maka dilanjutkan dengan pengujian hipotesis menggunakan analisis variansi dua jalan (2x3) dengan sel tak samaData hasil analisis variansi dua jalan $(2 \times 3)$ dengan sel tak sama dapat dilihat pada Tabel 7 . 
94 Jurnal Pendidikan Matematika dan IPA Vol. 9 No. 1 Januari 2018: 87-98

Tabel 7. Hasil Analisis Variansi Dua Jalan (2x3) Dengan Sel Tak Sama

\begin{tabular}{lccccc}
\hline \multicolumn{1}{c}{ Sumber } & JK & Dk & RK & $\boldsymbol{F}_{\boldsymbol{o b s}}$ & $\boldsymbol{F}_{\boldsymbol{a}}$ \\
\hline Pembelajaran (A) & 237,18 & 1 & 237,18 & 4,71 & 4,00 \\
Kemandirian Belajar (B) & 621,17 & 2 & 310,59 & 6,17 & 3,15 \\
Interaksi (AB) & 26,45 & 2 & 13,23 & 0,26 & 3,15 \\
Galat & 3223,46 & 64 & 50,37 & - & - \\
Total & 4108,26 & 69 & & & \\
\hline
\end{tabular}

Dari hasil analisis variansi dua jalan $(2 \times 3)$ dengan sel tak sama pada tabel 7 diketahui $F_{a}=4,71>$ $F_{0,05 ; 1 ; 64}=4,00, \quad$ sehingga $\quad H_{0 A}$ ditolak. Dengan demikian, hipotesis pertama teruji kebenarannya secara signifikan dan dapat diterima. Oleh karena itu, dapat disimpulkan bahwa terdapat perbedaan hasil belajar siswa pada kelas eksperimen yang diberi pembelajaran dengan metode eksperimen menggunakan software PhET dan hasil belajar siswa pada kelas kontrol yang diberi pembelajaran konvensional pada materi arus listrik dan hambatan listrik.

\section{Pembahasan}

Hasil rerata marginal dari hasil belajar siswa pada Tabel 3 diketahui bahwa kelas eksperimen yang diberi pembelajaran dengan metode eksperimen menggunakan software PhET sebesar 82,64 dan rerata marginal dari hasil belajar siswa untuk kelas kontrol yang diberi pembelajaran konvensional sebesar 78,84 atau lebih rendah dibandingkan dengan hasil belajar siswapada kelas eksperimen.

Hal ini disebabkan karena pembelajaran dengan metode eksperimen menggunakan software PhET membuat siswa dapat langsung mempraktikkan materi arus listrik dan hambatan listrik sehingga pembelajaran lebih interaktif dan menyenangkan bagi siswa serta mempermudah siswa dalam memahami materi dan menyimpulkan konsep-konsep yang ada pada materi tersebut Hal ini sejalan dengan penelitian yang dilakukan Prihartiningtyas, dkk (2013: 21) yang mengemukakan bahwa pembelajaran dengan menggunakan simulasi PhET membuat siswa tertarik dan semangat melakukan praktikum sehingga menuntaskan hasil belajar siswa. Selain itu, Malik (2010: 6) menyatakan bahwa strategi pembelajaran interaktif model simulasi merupakan strategi yang efektif, karena efektif dalam pemanfaatan waktu dan efektif dalam meningkatkan prestasi belajar siswa. Sejalan dengan penelitian yang dilakukan Taufiq (2008: 25) mengemukakan bahwa simulasi PhET memberikan kesan yang positif, menarik dan menghibur serta membantu penjelasan secara mendalam tentang suatu fenomena alam.

Pembelajaran dengan metode eksperimen menggunakan software PhET ini juga dapat menjelaskan materi yang masih bersifat abstrak seperti pada materi arus listrik dan hambatan listrik. Agar materi yang abstrak tersebut dapat dijelaskan secara nyata dan mudah untuk dipahami oleh siswa maka digunakan animasi-animasi yang terdapat pada software PhET. Dengan menggunakan animasi pada software 
PhET siswa dapat dengan jelas melihat bagaimana arah elektron dan arus listrik yang terjadi pada suatu rangkaian listrik sehingga dengan mudah dapat menyimpulkan konsepkonsep yang ada dari apa yang telah dilihatnya.

Berbeda dengan pembelajaran konvensional yang hanya mengandalkan metode ceramah yang kurang interaktif dan membosankan bagi siswa. Sejalan dengan penelitian yang dilakukan oleh Lailiyah dkk. (2009: 12) menyatakan bahwa pembelajaran dengan menggunakan simulasi lebih efektif dibandingkan pembelajaran dengan demonstrasi dan ceramah seperti yang dilakukan pada pembelajaran konvensional.Pada pembelajaran konvensional siswa hanya dituntut untuk mendengarkan apa yang dijelaskan guru, sehingga siswa tidak dapat mengalami langsung atau mempraktekkan materi yang masih bersifat abstrak. Hal ini membuat siswa bingung dalam menyimpulkan konsep-konsep yang ada pada materi arus listrik dan hambatan listrik.

Dari hasil analisis variansi dua jalan $(2 \times 3)$ dengan sel tak sama pada Tabel 7 diketahui $F_{b}=6,17>$ $F_{0,05 ; 2 ; 64}=3,15, \quad$ sehingga $H_{0 B}$ ditolak. Dengan demikian, hipotesis kedua teruji kebenarannya secara signifikan dan dapat diterima. Oleh karena itu, dapat disimpulkan bahwa terdapat perbedaan hasil belajar siswa antara siswa yang memiliki kemandirian belajar tinggi, sedang dan rendah pada materi arus listrik dan hambatan listrik. Berdasarkan Tabel 3 diketahui rerata marginal dari kedua kategori pembelajaran bahwa siswa dengan kemandirian belajar tinggi mempunyai rata-rata hasil belajar yang lebih tinggi sebesar 84,74 dari pada siswa dengan kemandirian belajar sedang maupun rendah yang mempunyai rata-rata hasil belajar masing-masing sebesar 80,22 dan 77,26. Sedangkan siswa dengan kemandirian belajar sedang mempunyai rata-rata hasil belajar yang lebih tinggi sebesar 80,22 dari pada siswa dengan kemandirian belajar rendah yang mempunyai ratarata hasil belajar sebesar 77,26.

Hasil penelitian ini menujukkan bahwa semakin tinggi kemandirian belajar siswa maka semakin tinggi pula hasil belajarnya. Menurut Darr dan Fisher (dalam Sugandi, 2013: 145) menyatakan bahwa "kemampuan belajar mandiri berkolerasi tinggi dengan keberhasilan belajar siswa". Pada siswa yang memiliki kemandirian belajar yang tinggi memiliki inisiatif dan motivasi yang tinggi pula dalam belajar, dapat menentukan kebutuhan belajar dan tujuan belajar serta dapat mengatur kinerja belajarnya sendiri, sehingga siswa yang memiliki kemandirian belajar tinggi lebih siap untuk menghadapi pelajaran dikelas. Siswa yang mandiri juga selalu mencari sendiri informasi-informasi yang berkaitan dengan materi yang dipelajarinya.

Hal tersebut sejalan dengan penelitian yang dilakukan oleh Tahar dan Enceng (2006: 99) menyatakan bahwa terdapat hubungan positif antara variabel kemandirian belajar terhadap hasil belajar. Artinya semakin tinggi skor kemandirian belajar cenderung semakin tinggi pula hasil belajar yang dibuktikan dengan hasil perhitungan $t_{\text {hitung }}>t_{\text {tabel }}$, siswa yang memiliki kemandirian belajar sedang, siswa yang tergolong 
kemandirian belajar sedang cenderung melakukan sesuatu itu setengah-setengah sehingga dalam proses pembelajaran yang dilakukan dikelas tidak seefektif dari siswa dengan kemandirian belajar tinggi. Sedangkan pada siswa yang memiliki kemandirian belajar rendah, siswa cenderung kurang aktif dan kurang memiliki inisiatif untuk mempelajari sendiri serta hanya mau menerima penjelasan guru saja sehingga hasil belajarnya rata-rata rendah.

Dari hasil analisis variansi dua jalan $(2 \times 3)$ dengan sel tak sama pada Tabel 7 diketahui $F_{a b}=0,26<$ $F_{0,05 ; 2 ; 64}=3,15, \quad$ sehingga $\quad H_{0 A B}$ diterima. Dengan demikian, hipotesis ketiga tidak teruji kebenarannya secara signifikan dan tidak dapat diterima. Oleh karena itu, dapat disimpulkan bahwa tidak terdapat interaksi antara metode pembelajaran dan kemandirian belajar terhadap hasil belajar siswa. Hal ini dikarenakan pada saat siswa melakukan eksperimen menggunakan software PhET, guru ikut serta membantu siswa dengan mendemonstrasikan cara-cara pengerjaan seperti cara merangkai rangkaian listrik dengan menggunakan software PhET. Sehingga semua siswa baik yang memiliki kemandirian tinggi, sedang dan rendah dapat dengan mudah memahami dan mengerjakan semua perintah pada LKS (Lembar Kerja Siswa) yang diberikan. Maka perbedaan hasil belajar siswa mengikuti karakteristik yang ada pada metode pembelajarannya.

Berdasarkan Tabel 3 diketahui bahwa rerata marginal atau nilai ratarata keseluruhan dari hasil belajar siswa yang diberi pembelajaran dengan metode eksperimen menggunakan software PhET sebesar 82,64 dan rerata marginal atau nilai keseluruhan dari hasil belajar siswa yang diberi pembelajaran konvensional sebesar 78,84. Sehingga dapat disimpulkan bahwa siswa yang memiliki kemandirian belajar tinggi, sedang dan rendah yang diberi pembelajaran dengan metode eksperimen menggunakan software PhET memberikan hasil belajar yang lebih baik dari pada pembelajaran konvensional pada materi arus listrik dan hambatan listrik, akan tetapi tidak signifikan, karena setelah dilakukan uji statistik tidak terdapat interaksi antara metode pembelajaran dan kemandirian belajar terhadap hasil belajar siswa.

\section{SIMPULAN}

Berdasarkan hasil pengolahan data dan pembahasan maka dapat disimpulkan bahwa terdapat perbedaan hasil belajar pada siswa yang diberi pembelajaran dengan metode eksperimen berbantuan software PhET dengan hasil belajar siswa yang diberi pembelajaran konvensional, hasil belajar siswa yang diberi pembelajaran dengan metode eksperimen berbantuan software PhET lebih baik dari pada hasil belajar pada siswa yang diberi pembelajaran konvensional. Terdapat perbedaan hasil belajar pada kelompok siswa dengan kemandirian belajar tinggi, sedang dan rendah. Tidak terdapat interaksi antara metode pembelajaran dan kemandirian belajar terhadap hasil belajar siswa. 
DAFTAR PUSTAKA

Albertus, D Lasmono, Sri Wahyuni, Fitriya S. (2012). Pengembangan Petunjuk Praktikum Berbasis Laboratorium Virtual (Virtual Laboratory) Pada Pembejalajaran Fisika di SMP/MTs. Jurnal Pembelajaran Fisika. Vol.1, No.3, 271-277.

Azis, Mohammad, Leny Yuanita, Yuni Sri Rahayu. (2014). Pengembangan Perangkat Pembelajaran Inkuiri Berbantuan Program Simulasi PheT untuk Melatihkan Keterampilan Proses dan Pemahaman Konsep IPA. Jurnal Penelitian Pendidikan Sains, Vol.3, No.2, 410-419.

Djamarah, S.B. dan Zain, A. (2010). Strategi Belajar Mengajar. Jakarta: Rineka Cipta.

Lailiyah, Eni. (2009). Perbandingan Efektivitas Metode Simulasi Javascript Terhadap Demonstrasi dan Ceramah Dalam Meningkatkan Kemampuan Siswa Untuk Materi Pemuaian dan Wujud Zat. Jurnal Pembelajaran Fisika Sekolah Menengah. Vol.1, No.1, 9-13.

Nurhayati, Syarifah Fadilah, Mutmainnah. (2014). Penerapan Metode Demonstrasi Berbantuan Software PhET Pada Materi Listrik Dinamis Kelas X di Madrasah Aliyah Negeri 1 Pontianak. Jurnal
Pendidikan Fisika dan Aplikasinya, Vol.4, No. 2, 1-7.

Prihatiningtyas, S, T. Prastowo, B. Jatmiko. (2013). "Implementasi Simulasi PhET dan KIT Sederhana Untuk Mengajarkan Keterampilan Psikomotor Siswa Pada Pokok Bahasan Alat Optik". Jurnal Pendidikan IPA Indonesia, Vol.2, No.1, 18-22.

Sari, Ana Kurnia, Chandra Ertikanto, Wayan Suana. (2015). Pengembangan LKS Memanfaatkan Laboratorium Virtual pada Materi Optik Fisis dengan Pendekatan Saintifik. Jurnal Pembelajaran Fisika, Vol.2, No.2, 1-12.

Siregar, Antomi. (2016). Pembelajaran Pengantar Fisika Kuantum Dengan Memanfaatkan Media PheTSimolation dan LKM Melalui Pendekatan Saintifik: Dampak Pada Minat dan Penguasaan Konsep Mahasiswa. Junal Ilmiah Pendidikan Fisika Al-BiRuNi. Vol.5, No.1, 53-60.

Sugandi, Asep. (2013). Pengaruh Pembelajaran Berbasis Masalah Dengan Setting Kooperatif Jigsaw Terhadap Kemandirian Belajar Siswa SMA. Jurnal Ilmiah Program Studi Matematika STKIP Siliwagi Bandung. Vol.2, No.2, 144-155.

Tahar, I. dan Enceng. (tahun) Hubungan Kemandirian Belajar dan Hasil Belajar Pada Pendidikan Jarak Jauh. Jurnal 
98 Jurnal Pendidikan Matematika dan IPA Vol. 9 No. 1 Januari 2018: 87-98

Pendidikan Terbuka dan Jarak Jauh. Vol. 7, No.2, 91-101.

Taufiq, M. (2008). Pembuatan Media Pembelajaran

Compact Disc Untuk Menampilkan Simulasi dan Virtual Labs Besaran-besaran Fisika. Jurnal Pijar MIPA, Vol. 3, No.3, 68-72.

Tutut Prasetiyanti, Sutrisno, Anis Rahmawati. (2014). Pembelajaran Training Inquiry Model Dengan Bantuan KWL Chart Terhadap Hasil Belajar Mahasiswa Pendidikan Teknik Bangunan Universitas Sebelas Maret Dalam Mata Kuliah Kontruksi Bangunan Gedung. Jurnal Pendidikan Teknik Bangunan, Vol.4, No.4, 1-7.
Yuniar Ekawati, Abdul Haris, $\mathrm{Hj}$ Bunga Dara Amin. (2015). Penerapan Media Simulasi Menggunakan Phet (Physics Education And Technology) terhadap Hasil Belajar Fisika Peserta Didik Kelas X SMA Muhammadiyah Limbung. Jurnal Pendidikan Fisika Universitas Muhammadiyah Makasar. Vol.3, No.1, 74-82. 